\title{
Landslide Event on 24 June in Sichuan Province, China: Preliminary Investigation and Analysis
}

\author{
Wanlin Meng ${ }^{1,2}$, Yeshuang $X u^{1,2, *}$, Wen-Chieh Cheng ${ }^{3}$ and Arul Arulrajah ${ }^{4}$ \\ 1 State Key Laboratory of Ocean Engineering, Collaborative Innovation Center for Advanced Ship and \\ Deep-Sea Exploration (CISSE), School of Naval Architecture, Ocean and Civil Engineering, Shanghai Jiao \\ Tong University, 800 Dong Chuan Road, Minhang District, Shanghai 200240, China; wlmeng@sjtu.edu.cn \\ 2 Key Laboratory of Land Subsidence Monitoring and Prevention, Ministry of Land and Resources \& \\ Shanghai Engineering Research Center of Land subsidence, Shanghai 200072, China \\ 3 Institute of Tunnel and Underground Structure Engineering, School of Civil Engineering, Xi'an University of \\ Architecture and Technology, 13 Yanta Rd., Xi'an 710055, China; w-c.cheng@xauat.edu.cn \\ 4 Department of Civil and Construction Engineering, Swinburne University of Technology, John St., \\ Hawthorn, VIC 3122, Australia; aarulrajah@swin.edu.au \\ * Correspondence: xuyeshuang@sjtu.edu.cn; Tel.: +86-21-3420-4301
}

Received: 20 October 2017; Accepted: 19 January 2018; Published: 23 January 2018

\begin{abstract}
This paper reports on a massive landslide event, in which 8 million cubic meters of earth and rocks slid down from the top of a mountain in the village of Xinmo, located in the county of Maoxian, in the province of Sichuan, China, on 24 June 2017. This landslide resulted in 10 fatalities and 73 people were reported as missing. This paper details the preliminary investigation, the joint-force rescue activity, and the analysis of the nearby topography, rainfall, and seismic fracture zone. The combined effects of large amounts of rainwater, steep topography, deep-seated sliding interface, and significant altitude difference between the highest point of the mountain and the Xinmo villagers' houses are considered as the main influencing factor that triggered this landslide event. To develop geological disaster-prone areas in the future, four main recommendations to reduce casualties and environmental impacts are provided in this paper.
\end{abstract}

Keywords: landslide; Xinmo; debris flow; seismic fracture zone

\section{Introduction}

China is a country that is severely affected by geological disasters [1,2], including landslides [3,4], land subsidence [5-8], mud-rock flow, and karst collapses [9]. Geological disasters in 2016 resulted in 370 deaths and an economic loss of 3.17 billion RMB (\$USD 480 million) [10]. Landslides are among the most serious geological disasters that occur in China. In 2014 alone, 8149 landslides in 10,937 geological disasters occurred in China [11].

Landslides can be triggered by factors such as rainfall [12-15], earthquakes [16-19], and urban construction activities. Landslides cause catastrophic damage to engineering infrastructures [20-22] and result in a large number of casualties $[23,24]$ in a number of cities and countries each year. In order to assess the losses caused by landslides, a variety of methods have been proposed, including computations of direct and indirect losses resulting from structure and infrastructure damage $[25,26]$.

In order to reduce the casualties and economic losses resulting from landslides, early warning systems (EWSs) have been established, which can be divided into several categories depending on the type of monitoring object. Rainfall monitoring is the most mature technique used in EWSs. Many early warning models have been developed in recent years, which are mainly based on daily rainfall, pre-rainfall, and previous soil moisture records [27-34]. Displacement monitoring is another important technique for EWSs [35]. GPS and InSAR combined with GIS can be applied to a wide range 
of displacement monitoring systems to carry out risk analysis [36-42], and displacement transducers can be used at specific locations. Moreover, other methods such as groundwater level monitoring can also provide a reference for EWSs.

Despite efforts made by researchers and the government, a catastrophic landslide occurred in the village of Xinmo, situated in the county of Maoxian, in the province of Sichuan, in 2017. This paper reports on this landslide event and the subsequent rescue work, which are then analyzed based on local rainfall and earthquakes records.

\section{Methodology}

\subsection{Preliminary Investigation}

The Xinmo village was struck by a catastrophic landslide at 5:38:55 a.m. on 24 June (Figure 1). Xinmo is located in the northwest of Chengdu, the capital of Sichuan. This village has been deemed as a hub of the Diexi-Songpinggou scenic area, which is famous for several barrier lakes that were formed by the Diexi Earthquake that occurred in 1933. In this landslide event, approximately 8 million cubic meters of earth and rocks—equivalent to more than 3000 Olympic-sized swimming pools—slid down the mountain from a height of $1100 \mathrm{~m}$ (the vertical distance between the highest point of the landslide and the Xinmo villagers' houses). The China Earthquake Networks Center (CENC) reported that the altitude of the landslide was located at a longitude of $103.65^{\circ} \mathrm{E}$ and a latitude of $32.09^{\circ} \mathrm{N}$, and its duration was estimated to be around 100 s. Figure 2a,b show the 3D model from Google Earth before the landslide and the photo taken after the event, respectively.
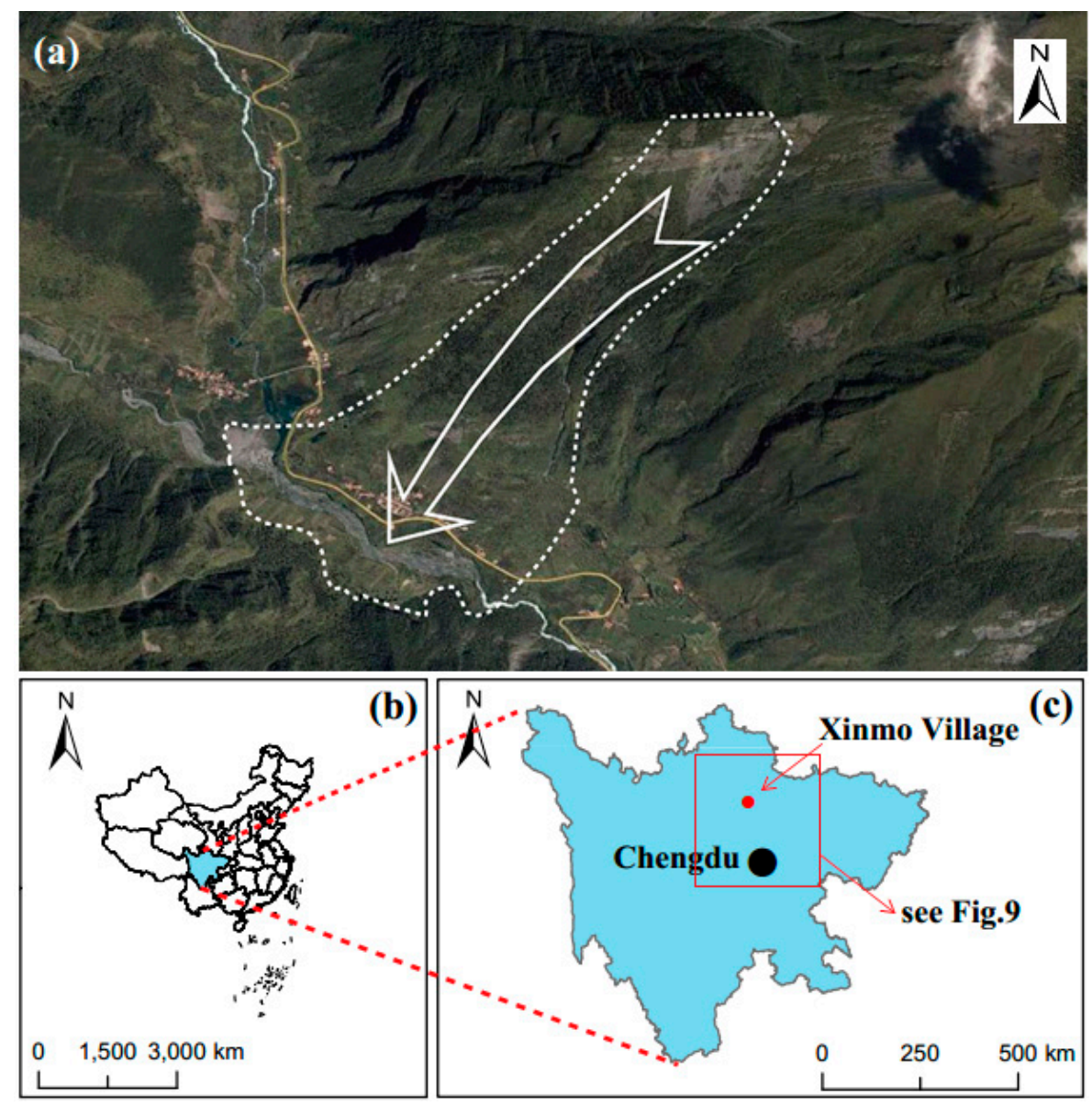

Figure 1. (a) Satellite image depicting the location of the landslide and nearby topography based on google maps. (b) Location of Sichuan. (c) Location of Xinmo. 


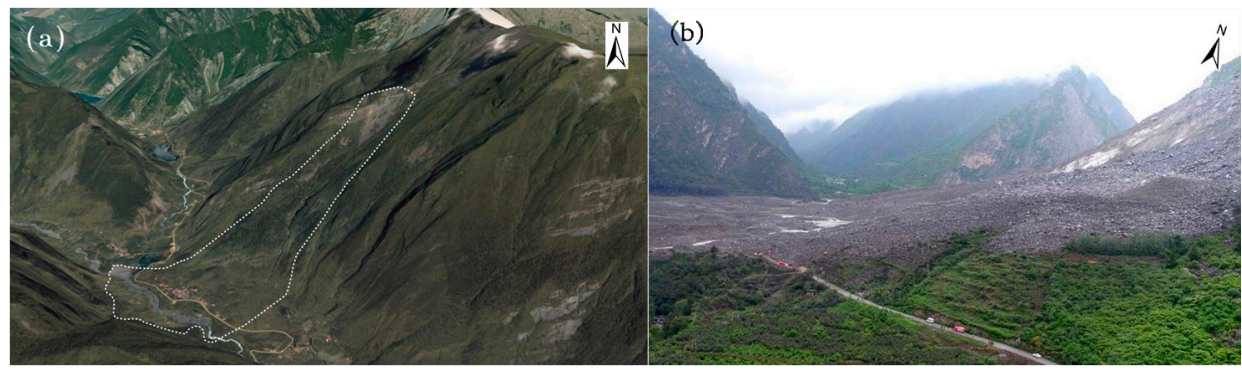

Figure 2. (a) 3D model from Google Earth before the landslide. (b) Photo taken after the landslide.

Figure 3 presents an overall view of the site after the landslide. As is evident, the landslide's horizontal and vertical trajectory projected $3000 \mathrm{~m}$ and about $1250 \mathrm{~m}$, respectively. In addition, the tributary of the Minjiang River was blocked by earth and rocks, which exacerbated the scale of this landslide. The landslide resulted in 10 deaths and with 73 people reported as missing. Three people (a couple with a one-month old baby) were later rescued on 28 June.

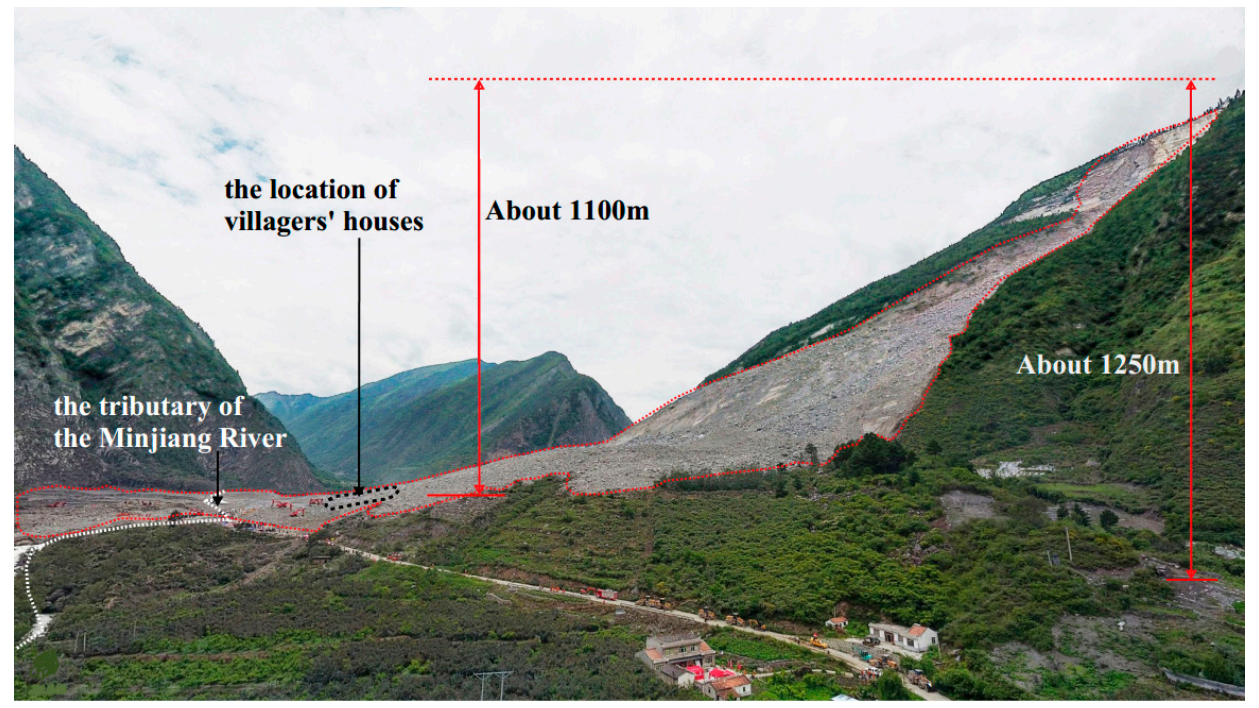

Figure 3. An overview of the landslide site.

Figure 4 shows a profile schematic of the landslide. The elevation before this landslide event was based on records from satellite data. The elevation after this landslide event was estimated according to the law of conservation of mass, while volume expansion during landslide is ignored. The section line is also shown in Figure 4. Preliminary investigation showed that the landslide can be divided into three main parts:

- Part A was the source of the landslide. The slope exposed after the landslide mainly ranged from 55 to 70 degrees, and the depth of the sliding interface reached about $60 \mathrm{~m}$. A width of $350 \mathrm{~m}$, a length of $450 \mathrm{~m}$, and an average depth of about $23 \mathrm{~m}$ made up a volume of 3.6 million cubic meters.

- Part B slid down under the influence of Part A, and it has a relatively gentler slope angle ranging from 25 to 35 degrees. An average width of $360 \mathrm{~m}$, a length of $945 \mathrm{~m}$, and an average depth of about $14 \mathrm{~m}$ made up a volume of 4.8 million cubic meters.

- Part $C$ received the earth and rocks slid from Part A and Part B. The villagers' houses at the toe of this slope and the Minjiang River were thus buried (see Figure 5a,b) and clogged (see Figure 5c,d). 


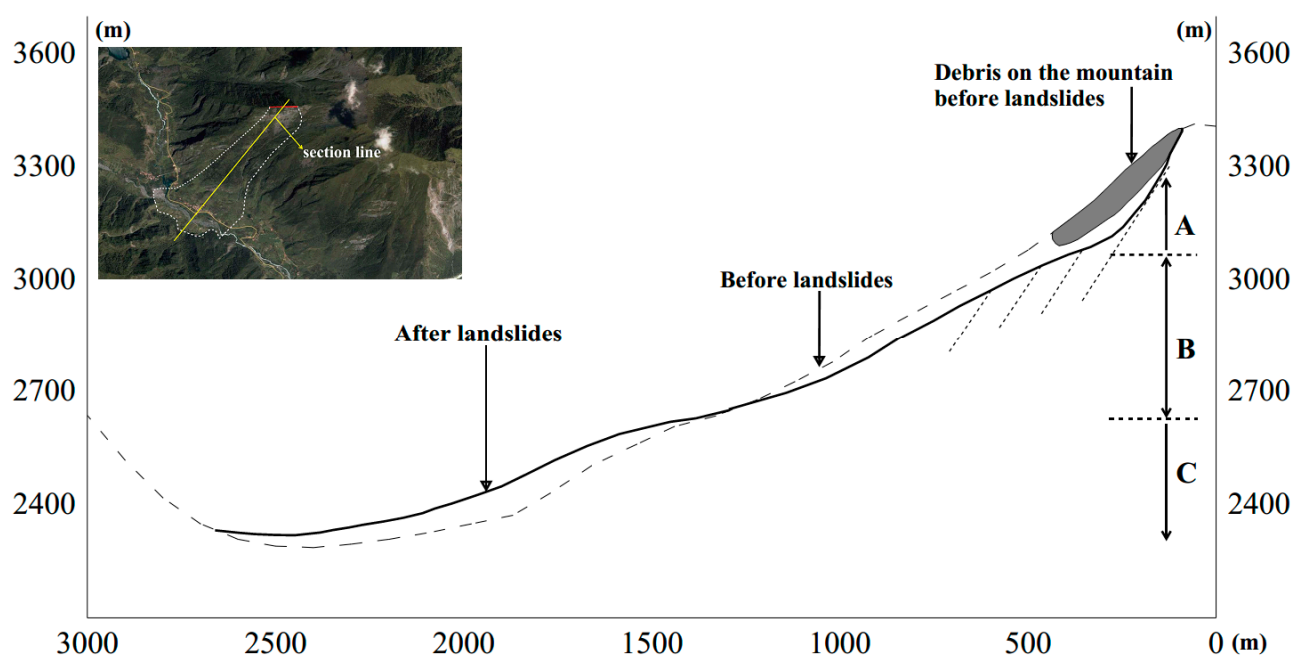

Figure 4. A profile of the landslide.

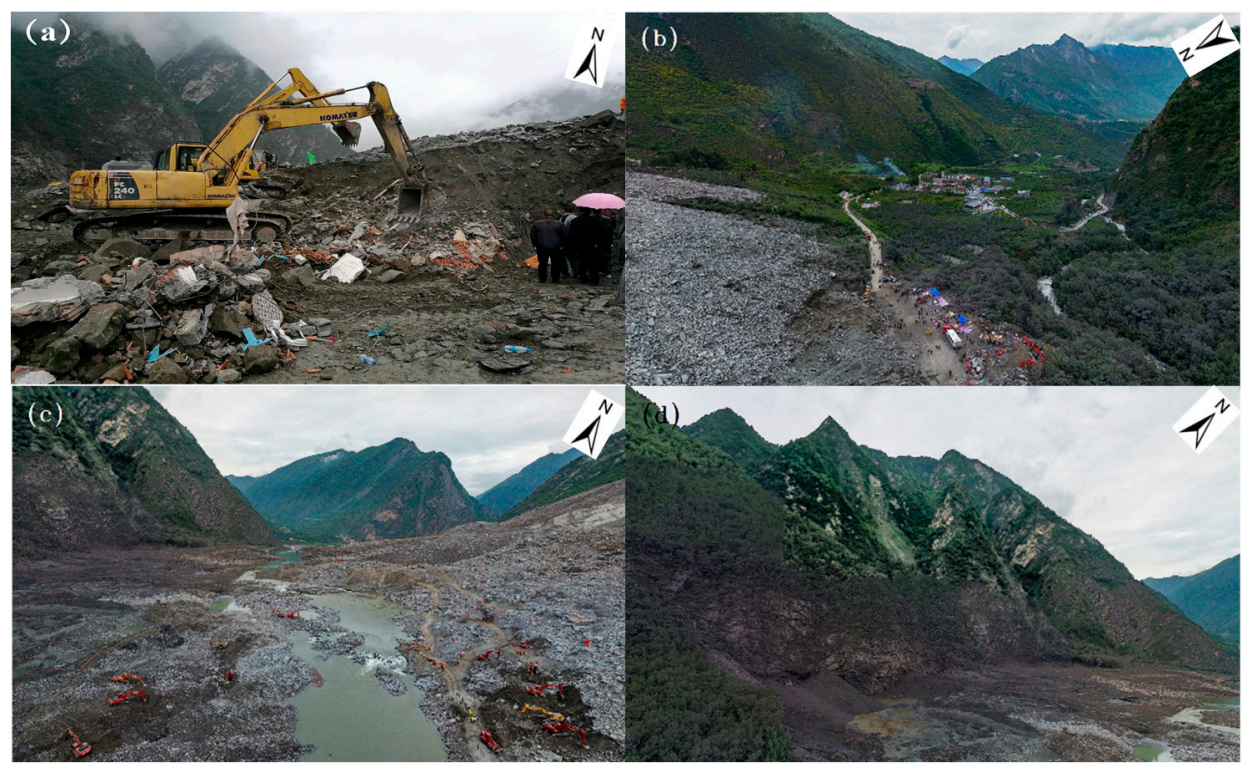

Figure 5. Close view of the landslide site: (a) Excavators involved in the rescue operation. (b) Houses not affected by the landslide, and the set-up of the rescue operation headquarter. (c) River being dredged after the landslide. (d) Debris of the landslide accumulated at the foot of the mountain.

\subsection{Data Source}

In order to analyze the event, the weather data records of Maoxian County were collected from the National Meteorological Center of China Meteorological Administration (NMC), which includes the annual average rainfall in Maoxian, the monthly average highest temperature, the monthly average lowest temperature, and the rainfall recorded by meteorological stations a week prior to the disaster. Seismic data was collected from the United States Geological Survey (GUGS).

\section{Rescue Effort}

This massive landslide has been deemed as one of the most serious landslide disaster ever to hit Sichuan. The joint-force rescue operation involved more than 3200 rescue personnel, including firefighters, armed police, experts, and doctors who came from Maoxian as well as other counties such as Aba and Songpan. In addition, more than 150 vehicles, two helicopters, and six unmanned aerial 
vehicles (UAVs) attended the joint-force rescue activity and played a leading role in excavating and investigating the distress area. As shown in Figure 6, cobbles and gravels hurled by the landslide body, with a weight exceeding $100 \mathrm{kN}$ piled up at the lower landslide body, which brought about considerable difficulty in undertaking rescue works. In addition, a secondary landslide hit the disaster site at 11 a.m. on 27 June 2017. Fortunately, the displacement was monitored by a slope synthetic aperture radar (S-SAR) [36,37,41], and the operators ordered an evacuation prior to the landslide event, resulting in no further casualties. The rescue lasted about a week, with 3 people rescued and 10 bodies recovered. One hundred fifty-four tourists were safely transferred to other areas unaffected by the landslide. The total cost for this rescue operation was difficult to estimate, as all the rescuers and machineries involved in this rescue came from various parts of the country, but is estimated to cost in the tens of millions (US Dollars). In addition, another 412.1 million RMB (60.6 million USD) has been planned to invest into the reconstruction.

In addition, the geological disaster investigation in Sichuan was carried out to avoid the recurrence of similar geological disasters. Since October 2017, roads and rivers have been dredged, and roads have been rebuilt. This mitigation exercise is expected to be completed by the end of 2018. The destroyed houses are being replaced with new houses that are being constructed in the village of Jiaochang (beside Xinmo).

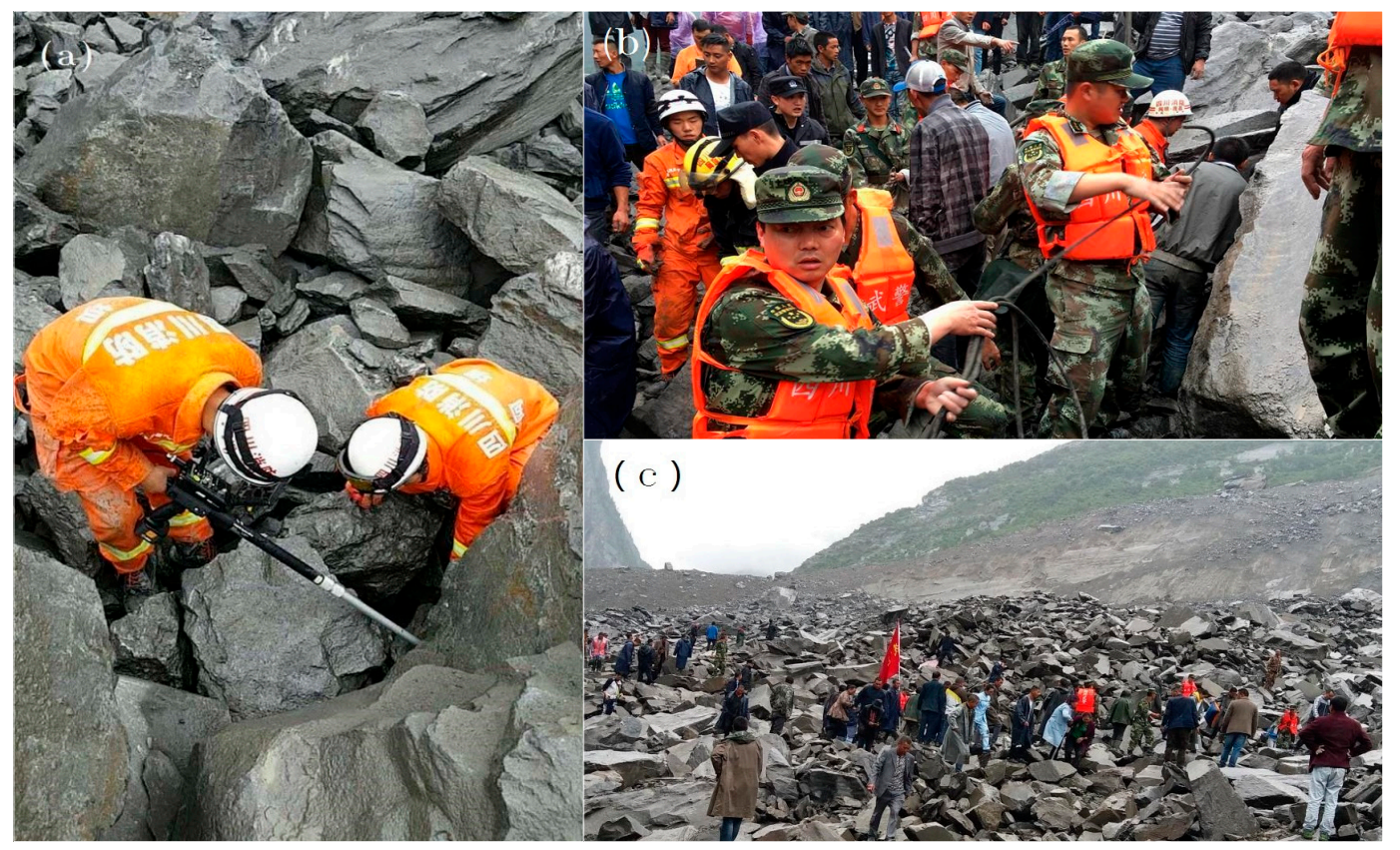

Figure 6. Joint-force rescue activity. (a) Firefighters who are detecting signs of life. (b) Armed police involved in the rescue. (c) People involved in the rescue.

\section{Analysis and Discussions}

\subsection{Rainfall and Topography}

Maoxian, located northwest of the Sichuan Basin, is located in mountainous terrain, with an annual rainfall of $477.5 \mathrm{~mm}$ (see Figure 7). In this landslide case study, rainfall water was considered as the most important influence factor [27-30]. From 1 to 24 June, 15 days of rainfall was recorded, and a $4.2 \mathrm{~mm}$ rainfall event was also recorded (see Figure 7) the day before the landslide. The rainwater significantly deteriorated the sliding interface. The shear stresses due to deterioration of the sliding interface acted along the shear band (or potential sliding surface) resulted in reduced shear strength available at the shear band, which resulted in the displacement of the earth and rocks above, thereby triggering this massive landslide. 


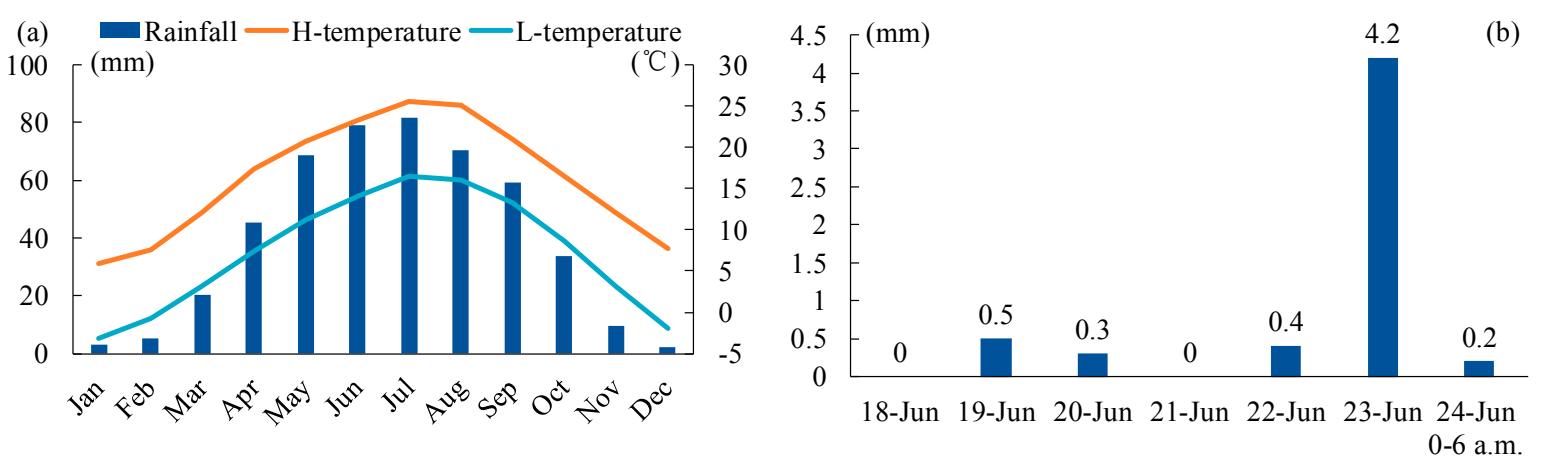

Figure 7. (a) The average monthly rainfall, the highest temperature (H-temperature), and the lowest temperature (L-temperature) in Maoxian. (b) The rainfall in Maoxian prior to the landslide.

The topography at Xinmo contributed to the formation of this landslide (see Figure 4). The repose angle of steep slope reached up to 70 degrees, which was a triggering factor for sliding failure. Moreover, according to remote sensing images shown in Figure 8, the vegetation at the top of the mountain was damaged before sliding, reducing the shear strength of soil enhanced by the root system of vegetation, thereby decreasing the sliding resistance. It is the authors' opinion that a larger volume of earth and rocks attributed to the deep-seated sliding interface contributed to the considerable weight of the earth and rocks.
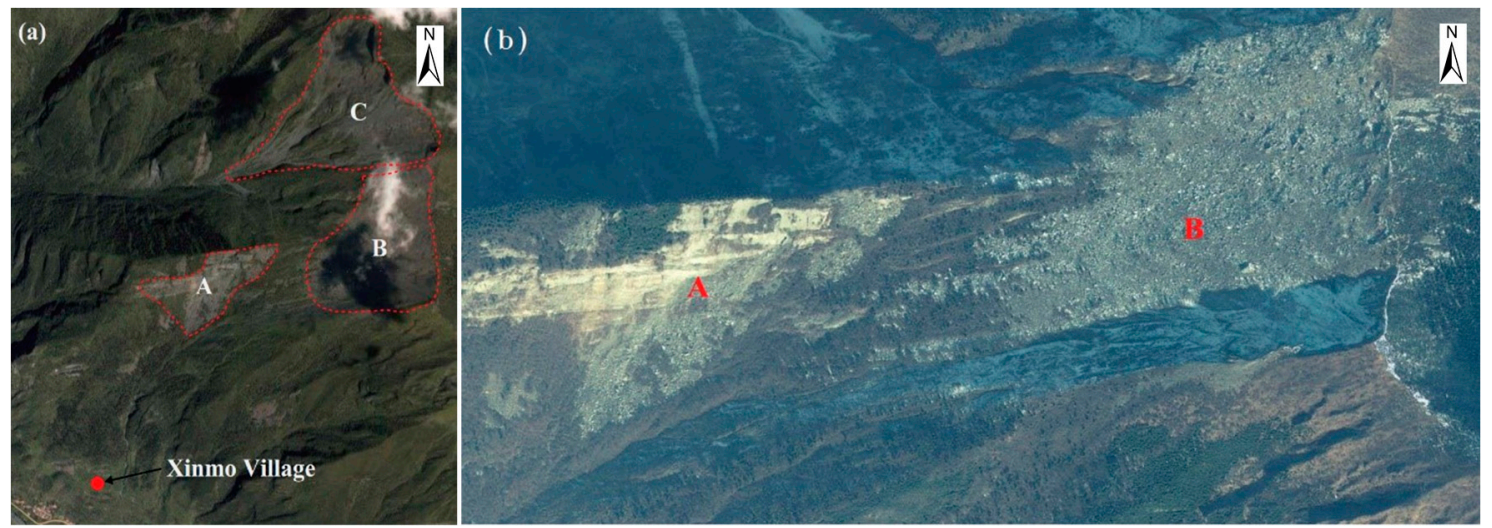

Figure 8. Gravels on the top of the mountain before landslides. (a) Three parts A, B, and C of gravels. (b) An enlarged image of A and B.

The volume of the earth and rocks, which slid down from the top of the mountain, was approximately 8 million cubic meters. The sliding interface reached a depth of about $60 \mathrm{~m}$. The altitude difference between the highest point of the landslide and the houses of Xinmo was approximately $1100 \mathrm{~m}$. The combined effects of the large amount of rainwater, the steep topography, the deep-seated sliding interface, and the considerable altitude difference between the highest point of the mountain and the Xinmo villagers' houses enhanced the damage due to the debris flow, thereby severely impacting the Xinmo villagers as well as the surface traffic in the vicinity.

\subsection{Seismic Fracture Zone in Sichuan}

Figure 9 shows the complicated geological conditions around Xinmo. The surface layer of the mountains is a Quaternary sedimentary layer and the rock exposed after the landslide is from the Triassic period. The sliding of earth and rocks took place along the interface between the Quaternary sedimentary layers and the Triassic layers (see Figure 4). Thus, the interface deterioration due to 
the reduced shear strength caused by the infiltration of the pre-event rainfall can be considered the triggering mechanism for the landslide event.

Figure 9 also depicts the location of Xinmo, which is near the fracture zone northwest of the Sichuan Basin. The fracture zone includes Longmen Shan Thrust Fault, Minjiang Thrust Fault, Tazang Fault, Huya Thrust Fault, and Qingchuan Fault [43-47]. Thus, the landslide occurred at a geological disaster-prone area. Five earthquakes greater than Ms 7.0 have struck this area in the past. In 1933, the Diexi earthquake (Ms 7.5, Mw 7.3) struck the Diexi city, and the distress area covered Xinmo, causing more than 6800 deaths. In 1976, two earthquakes (Ms 7.2, Mw 6.7; Ms 7.2, Mw 6.9) hit the Songpan and Pingwu counties, which are located about $150 \mathrm{~km}$ away from Xinmo. The most recent earthquakes that occurred near Xinmo are the Wenchuan earthquake (2008, Ms 8.0, Mw 7.9) and the Lushan earthquake (2010, Ms 7.0, Mw 6.6). The epicenter of the Wenchuan earthquake was $114 \mathrm{~km}$ away from Xinmo, while the Lushan earthquake was further away from Xinmo. The Wenchuan earthquake eventually caused more than 69,000 deaths, 18,000 people were reported missing, and many associated landslides were triggered $[18,19]$. It is the authors' and many other geologists' opinion that landslide and seismic activities should have case-specific relationships, but further investigation is deemed necessary to ascertain this postulation $[48,49]$.

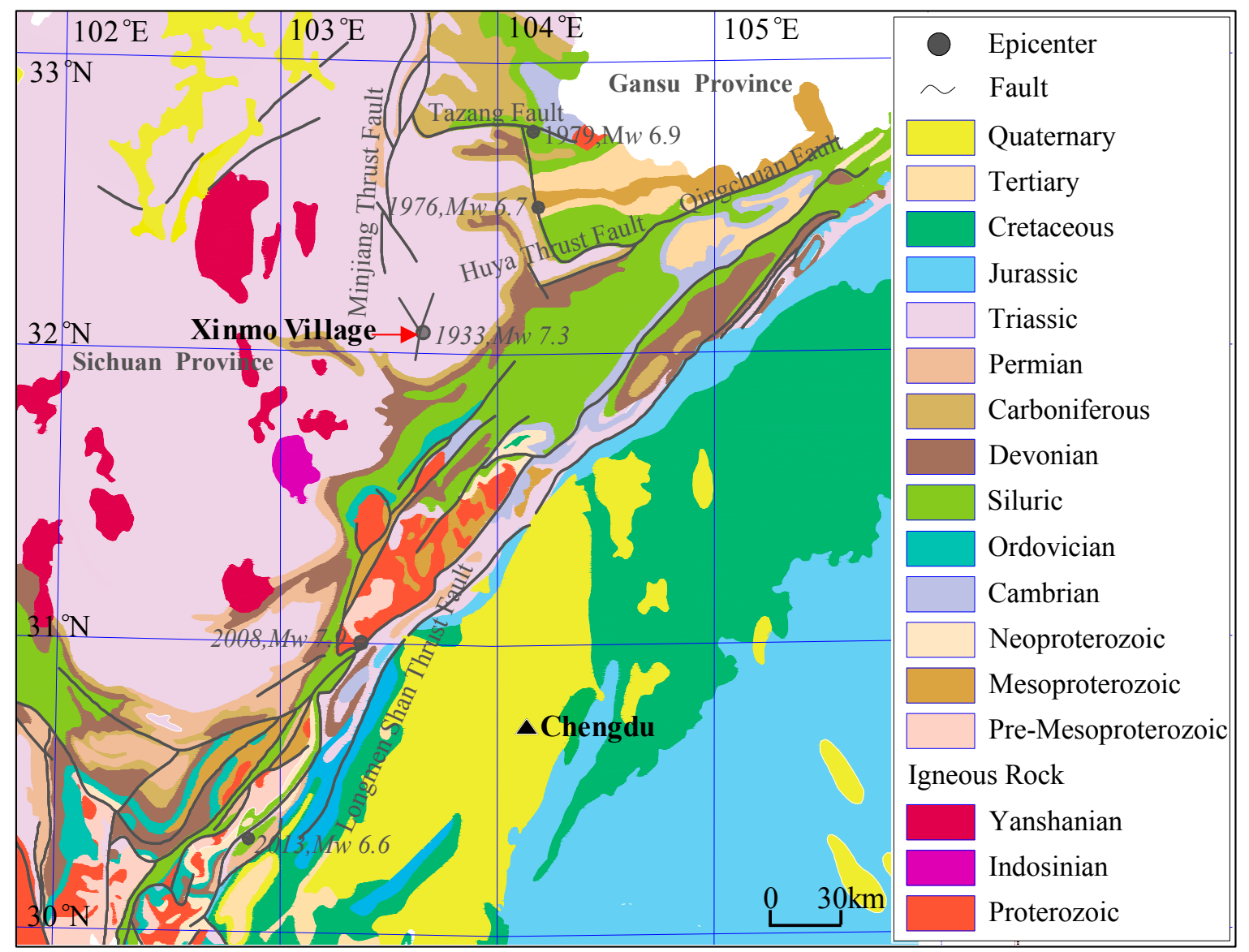

Figure 9. Earthquakes ( $\mathrm{Mw}>6.5$, after 1900) and faults near Xinmo (geographical location in red rectangle of Figure 1c).

\subsection{Recommendations}

Landslides are considered one of the most serious natural disasters that can occur in Mainland China and worldwide [23-26]. However, such a massive scale of landslide, with approximately 8 million cubic meters of earth and rocks displaced, is rare. Four main recommendations given in this paper for future development of geological disaster-prone areas are as follows: 
(1) Firstly, key geological disaster monitoring areas should be investigated. In fact, the investigation is one of the major difficulties for geological disaster prevention. It has been reported that, in China, in 2010, one-third of geological disasters occurred outside monitored areas [50]. Therefore, GIS and other methods should be applied to a more extensive range. The analysis combined with topography, geology, direct economic losses, and potential losses should be used for the division of landslide-prone areas. The geomorphology of landslide areas can also be reconstructed based on GIS or GPS data [51]. Moreover, artificial intelligence can also be used [52,53]. These technologies can aid in predicting geological disasters.

(2) More economical and reasonable methods for slope reinforcement, continuous monitoring, and resident migration should be selected considering monitoring costs and potential losses $[25,54]$.

(3) For continuous monitoring areas, an EWS is necessary. Local weather stations and satellites should be used for continuous rainfall monitoring and displacement monitoring. A threshold should also be established based on rainfall and displacement, considering topography, geology, potential losses, and degree of risk.

(4) Displacement measuring devices such as GPS, distributed optic fibers and 3D laser scanners, should be deployed in small key continuous monitoring areas. The cost of a monitoring system with a range of kilometers can been economically controlled to be in the order of tens of thousands US dollars.

In addition, villagers who live in the geological disaster-prone areas should be educated on planned evacuation routes released by responsible authorities, and evacuation practice should be performed on a regular basis.

\section{Conclusions}

This paper reports on the massive landslide event that occurred on 24 June 2017 in Sichuan, China. Based upon the preliminary investigation and analysis, the following conclusions can be drawn:

1 A large-scale landslide event, with about 8 million cubic meters of earth and rocks, occurred at Xinmo, resulting in 10 fatalities and 73 people reported as missing. The debris flow hurled cobbles and gravels that weighed more than $100 \mathrm{kN}$ into the valley, clogging a $2 \mathrm{~km}$ section of the Minjiang river. In preliminary investigations, the debris flow's horizontal and vertical trajectory was projected as $3000 \mathrm{~m}$ and $1250 \mathrm{~m}$, respectively.

2 The combined effects of large amounts of rainwater, steep topography, deep-seated sliding interface, and significant altitude difference between the highest point of the mountain and the Xinmo villagers' houses enhanced the power of the debris flow, leading to severe casualties and environmental impacts.

3 Early warning systems and continuous monitoring by cost-effective strain sensing technology should be deployed for geological disaster-prone areas. Villagers who live in geological disaster-prone areas should be educated on planned evacuation routes, thereby reducing casualties in future similar incidents.

Acknowledgments: The research work described herein was funded by the National Nature Science Foundation of China (NSFC) (Grant No. 41672259). It was also supported by Key Laboratory of Land Subsidence Monitoring and Prevention, Ministry of Land and Resources in China (No. KLLSMP201502). These financial supports are gratefully acknowledged.

Author Contributions: Wanlin Meng carried out data acquisition and consolidation. Yeshuang $\mathrm{Xu}$ and Wen-Chieh Cheng prepared this manuscript. Arul Arulrajah revised the manuscript. All authors read and approved the final manuscript.

Conflicts of Interest: The authors declare no conflict of interest. 


\section{References}

1. Wu, Y.; Liu, X.; Wang, J.; Liu, L.; Shi, P. Landslide and Debris Flow Disasters in China. In Natural Disasters in China; Shi, P., Ed.; IHDP/Future Earth-Integrated Risk Governance Project Series 2016; Springer: Berlin/Heidelberg, Germany, 2016.

2. Xu, Y.S.; Zhang, D.X.; Shen, S.L.; Chen, L.Z. Geo-hazards with characteristics and prevention measures along the coastal regions of China. Nat. Hazards 2009, 49, 479-500. [CrossRef]

3. Bai, S.B.; Wang, J.; Lv, G.N.; Zhou, P.G.; Hou, S.S.; Xu, S.N. GIS-based logistic regression for landslide susceptibility mapping of the Zhongxian segment in the Three Gorges area, China. Geomorphology 2010, 115, 23-31. [CrossRef]

4. Qi, S.W.; Xu, Q.; Lan, H.X.; Zhang, B.; Liu, J.Y. Spatial distribution analysis of landslides triggered by 2008.5.12 Wenchuan Earthquake, China. Eng. Geol. 2010, 116, 95-108. [CrossRef]

5. Shen, S.L.; Xu, Y.S. Numerical evaluation of land subsidence induced by groundwater pumping in Shanghai. Can. Geotech. J. 2011, 48, 1378-1392. [CrossRef]

6. Xu, Y.S.; Shen, S.L.; Ren, D.J.; Wu, H.N. Factor analysis of land subsidence in Shanghai: A view based on Strategic Environmental Assessment. Sustainability 2016, 8, 573. [CrossRef]

7. Wu, Y.X.; Shen, S.L.; Yuan, D.J. Characteristics of dewatering induced drawdown curve under barrier effect of retaining wall in aquifer. J. Hydrol. 2016, 539, 554-566. [CrossRef]

8. Shen, S.L.; Wu, H.N.; Cui, Y.J.; Yin, Z.Y. Long-term settlement behavior of the metro tunnel in Shanghai. Tunn. Undergr. Space Technol. 2014, 40, 309-323. [CrossRef]

9. Cui, Q.L.; Wu, H.N.; Shen, S.L.; Xu, Y.S.; Ye, G.L. Chinese karst geology and measures to prevent geohazards during shield tunnelling in karst region with caves. Nat. Hazards 2015, 77, 129-152. [CrossRef]

10. MLR (Ministry of Land and Resources of the Peoples' Republic of China). National Geological Disaster Bulletin; MLR (Ministry of Land and Resources of the Peoples' Republic of China): Beijing, China, 2016. (In Chinese)

11. MLR (Ministry of Land and Resources of the Peoples' Republic of China). National Geological Disaster Bulletin; MLR (Ministry of Land and Resources of the Peoples' Republic of China): Beijing, China, 2014. (In Chinese)

12. Caracciolo, D.; Arnone, E.; Conti, F.L.; Noto, L.V. Exploiting historical rainfall and landslide data in a spatial database for the derivation of critical rainfall thresholds. Environ. Earth Sci. 2017, 76, 222. [CrossRef]

13. Yu, F.C.; Chen, T.C.; Lin, M.L.; Chen, C.Y.; Yu, W.H. Landslides and Rainfall Characteristics Analysis in Taipei City during the Typhoon Nari Event. Nat. Hazards 2006, 37, 153-167. [CrossRef]

14. Ciurleo, M.; Cascini, L.; Calvello, M. A comparison of statistical and deterministic methods for shallow landslide susceptibility zoning in clayey soils. Eng. Geol. 2017, 223, 71-81. [CrossRef]

15. Cascini, L.; Ciurleo, M.; Di Nocera, S. Soil depth reconstruction for the assessment of the susceptibility to shallow landslides in fine-grained slopes. Landslides 2017, 14, 459-471. [CrossRef]

16. Romeo, S.; Di Matteo, L.; Melelli, L.; Cencetti, C.; Dragoni, W.; Fredduzzi, A. Seismic-induced rockfalls and landslide dam following the October 30, 2016 earthquake in Central Italy. Landslide 2017, 14, 1457-1465. [CrossRef]

17. Qi, S.W.; Lan, H.X.; Dong, J.Y. An analytical solution to slip buckling slope failure triggered by earthquake. Eng. Geol. 2014, 194, 4-11. [CrossRef]

18. Shi, Z.M.; Wang, Y.Q.; Peng, M.; Chen, J.F.; Yuan, J. Characteristics of the landslide dams induced by the 2008 Wenchuan earthquake and dynamic behavior analysis using large-scale shaking table tests. Eng. Geol. 2014, 194, 25-37. [CrossRef]

19. Tang, H.M.; Liu, X.; Hu, X.L.; Griffiths, D.V. Evaluation of landslide mechanisms characterized by high-speed mass ejection and long-run-out based on events following the Wenchuan earthquake. Eng. Geol. 2014, 194, 12-24. [CrossRef]

20. Yin, Y.P.; Li, B.; Wang, W.P.; Zhan, L.T.; Xue, Q.; Gao, Y.; Zhang, N.; Chen, H.Q.; Liu, T.K.; Li, A. Mechanism of the December 2015 Catastrophic Landslide at the Shenzhen Landfill and Controlling Geotechnical Risks of Urbanization. J. Eng. 2016, 2, 230-249. [CrossRef]

21. Listo, F.L.R.; Vieira, B.C. Mapping of risk and susceptibility of shallow-landslide in the city of Sao Paulo, Brazil. Geomorphology 2012, 169-170, 30-44. [CrossRef]

22. Antronico, L.; Borrelli, L.; Coscarelli, R.; Gullà, G. Time evolution of landslide damages to buildings: The case study of Lungro (Calabria, southern Italy). Bull. Eng. Geol. Environ. 2015, 74, 47-59. [CrossRef] 
23. Schuster, R.L.; Fleming, R.W. Economic losses and fatalities due to landslides. Bull. Assoc. Eng. Geol. 1986, 23, 11-28. [CrossRef]

24. Petley, D. Global patterns of loss of life from landslides. Geology 2012, 40, 927-930. [CrossRef]

25. Klose, M.; Damn, B.; Terhorst, B. Landslide cost modeling for transportation infrastructures: A methodological approach. Landslides 2015, 12, 321-334. [CrossRef]

26. Del Soldato, M.; Bianchini, S.; Calcaterra, D.; De Vita, P.; Martire, D.D.; Tomas, R.; Casagli, N. A new approach for landslide-induced damage assessment. Geomat. Nat. Hazards Risk 2017, 8, 1524-1537. [CrossRef]

27. Antronico, L.; Borrelli, L.; Coscarelli, R.; Pasqua, A.A.; Petrucci, O.; Gullà, G. Slope movements induced by rainfalls damaging an urban area: The Catanzaro case study (Calabria, southern Italy). Landslides 2013, 10, 801-814. [CrossRef]

28. Huang, J.; Ju, N.P.; Liao, Y.J.; Liu, D.D. Determination of rainfall thresholds for shallow landslides by a probabilistic and empirical method. Nat. Hazards Earth Syst. Sci. 2015, 15, 2715-2723. [CrossRef]

29. Segoni, S.; Battistini, A.; Rossi, G.; Rosi, A.; Lagomarsino, D.; Catani, F.; Moretti, S.; Casagli, N. An operational landslide early warning system at regional scale based on space-time-variable rainfall thresholds. Nat. Hazards Earth Syst. Sci. 2015, 15, 853-861. [CrossRef]

30. Salciarini, D.; Fanelli, G.; Tamagnini, C. A probabilistic model for rainfall-induced shallow landslide prediction at the regional scale. Landslides 2017, 14, 1731-1746. [CrossRef]

31. Yin, Z.Y.; Jin, Y.F.; Shen, S.L.; Hicher, P.Y. Optimization techniques for identifying soil parameters in geotechnical engineering: Comparative study and enhancement. Int. J. Numer. Anal. Methods Geomech. 2018, 42, 70-94. [CrossRef]

32. Shen, S.L.; Wang, Z.F.; Yang, J.; Ho, E.C. Generalized approach for prediction of jet grout column diameter. J. Geotech. Geoenviron. Eng. 2017, 139, 2060-2069. [CrossRef]

33. Wu, H.N.; Shen, S.L.; Liao, S.M.; Yin, Z.Y. Longitudinal structural modelling of shield tunnels considering shearing dislocation between segmental rings. Tunn. Undergr. Space Technol. 2015, 317-323. [CrossRef]

34. Shen, S.L.; Cui, Q.L.; Ho, E.C.; Xu, Y.S. Ground response to multiple parallel microtunneling operations in cemented silty clay and sand. J. Geotech. Geoenviron. Eng. 2016, 142, 1-11. [CrossRef]

35. Gullà, G.; Peduto, D.; Borrelli, L.; Antronico, L.; Fornaro, G. Geometric and kinematic characterization of landslides affecting urban areas: The Lungro case study (Calabria, Southern Italy). Landslides 2017, 14, 171-188. [CrossRef]

36. Traglia, F.D.; Nolesini, T.; Ciampalini, A.; Solari, L.; Frodella, W.; Bellotti, F.; Fumagalli, A.; Rosa, G.D.; Casagli, N. Tracking morphological changes and slope instability using spaceborne and ground-based SAR data. Geomorphology 2017, 300, 95-112. [CrossRef]

37. Rosi, A.; Tofani, V.; Stefanelli, C.T.; Agostini, A.; Catani, F.; Casagli, N. The new landslide inventory of Tuscany(Italy) updated with PS-InSAR: Geomorphological features and landslide distribution. Landslides 2017. [CrossRef]

38. Bianchini, S.; Solari, L.; Casagli, N. A Gis-based procedure for landslide intensity evaluation and specific risk analysis supported by persistent scatterers interferometry (PSI). Remote Sens. 2017, 9, 1093. [CrossRef]

39. Chimidi, G.; Raghuvanshi, T.K.; Suryabhagavan, K.V. Landslide hazard evaluation and zonation in and around Gimbi town, western Ethiopia-A GIS-based statistical approach. Appl. Geomat. 2017, 9, 219-236. [CrossRef]

40. Intrieri, E.; Raspini, F.; Fumagalli, A.; Lu, P.; Conte, S.D.; Farina, P.; Allievi, J.; Ferretti, A.; Casagli, N. The Maoxian landslide as seen from space: Detecting precursors of failure with Sentinel-1 data. Landslides 2017. [CrossRef]

41. Ferlisi, S.; Peduto, D.; Gullà, G.; Nicodemo, G.; Borrelli, L.; Fornaro, G. The Use of DInSAR Data for the Analysis of Building Damage Induced by Slow-Moving Landslides. Eng. Geol. Soc. Territ. 2015, 2, 1835-1839. [CrossRef]

42. Antronico, L.; Borrelli, L.; Peduto, D.; Fornaro, G.; Gullà, G.; Paglia, L.; Zeni, G. Conventional and innovative techniques for the monitoring of displacements in landslide affected area. In Landslide Science and Practice: Early Warning, Instrumentation and Monitoring; Margottini, C., Canuti, P., Sassa, K., Eds.; Springer: Berlin/Heidelberg, Germany, 2013; Volume 2, pp. 125-131.

43. Chen, Q.C.; Feng, C.J.; Meng, W.; Qin, X.H.; An, Q.M. Analysis of in situ stress measurements at the northeastern section of the Longmenshan fault zone after the 5.12 Wenchuan earthquake. Chin. J. Geophys. 2012, 55, 3923-3932. [CrossRef] 
44. Chai, J.C.; Shen, J.S.L.; Liu, M.D.; Yuan, D.J. Predicting performance of embankments on PVD improved subsoils. Comput. Geotech. 2018, 93, 222-231. [CrossRef]

45. Shen, S.L.; Wang, Z.F.; Cheng, W.C. Estimation of lateral displacement induced by jet grouting in clayey soils. Geotechnique 2017, 67, 621-630. [CrossRef]

46. Xu, Y.S.; Shen, S.L.; Wu, H.N.; Zhang, N. Risk and impacts on the environment of free-phase biogas in Quaternary deposits along the coastal region of Shanghai. Ocean Eng. 2017, 137, 129-137. [CrossRef]

47. Wu, Y.X.; Shen, J.S.; Cheng, W.C.; Hino, T. Semi-analytical solution to pumping test data with barrier, wellbore storage, and partial penetration effects. Eng. Geol. 2017, 226, 44-51. [CrossRef]

48. Ouyang, C.J.; Zhao, W.; He, S.M.; Wang, D.P.; Zhou, S.; An, H.C.; Wang, Z.W.; Cheng, D.X. Numerical modeling and dynamic analysis of the 2017 Xinmo landslide in Maoxian Country, China. J. Mt. Sci. 2017, 14, 1701-1711. [CrossRef]

49. Su, L.J.; Hu, K.H.; Zhang, W.F.; Wang, J.; Lei, Y.; Zhang, C.L.; Cui, P.; Alessandro, P.; Zheng, Q.H. Characteristics and triggering mechanism of Xinmo landslide on 24 June 2017 in Sichuan, China. J. Mt. Sci. 2017, 14, 1689-1700. [CrossRef]

50. Tang, T.; Zhang, M.S.; Xue, Q.; Bi, J.B. Landslide monitoring and early-warning: An overview. Geol. Rev. 2012, 3, 533-541. [CrossRef]

51. Soldato, M.D.; Riquelme, A.; Tomas, R.; Vita, P.D.; Moretti, S. Geomorphological investigation based on 3D historical reconstruction. In Geosciences on a Changing Planet: Learning from the Past, Exploring the Future; Società Geologica Italiana: Roma, Italy, 2016.

52. Chen, W.; Pourghasemi, H.R.; Kornejady, A.; Zhang, N. Landsldie spatial modeling: Introducing new ensembles of ANN, MaxEnt, and SVM machine learning techniques. Geoderma 2017, 305, 314-327. [CrossRef]

53. Lyu, H.M.; Sun, W.J.; Shen, S.L.; Arulrajah, A. Flood risk assessment in metro systems of mega-cities using a GIS-based modeling approach. Sci. Total Environ. 2018. [CrossRef]

54. Highland, L.M.; Bobrowsky, P. Appendix C. Introduction to Landslide Stabilization and Mitigation. In The Landslide Handbook-A Guide to Understanding Landslides; USGS: Ritton, WV, USA, 2008.

(C) 2018 by the authors. Licensee MDPI, Basel, Switzerland. This article is an open access article distributed under the terms and conditions of the Creative Commons Attribution (CC BY) license (http:/ / creativecommons.org/licenses/by/4.0/). 